\title{
PENGARUH NILAI TUKAR MATA UANG DAN TINGKAT SUKU BUNGA TERHADAP PERKEMBANGAN INDEKS HARGA SAHAM GABUNGAN DI BURSA EFEK INDONESIA PERIODE 2009-2013
}

\author{
Muh. Halim Palatte ${ }^{1}$ \\ Akbar $^{2}$
}

No. HP 0853980144961

\begin{abstract}
ABSTRAK
Indeks Harga Saham Gabungan (IHSG) merupakan indeks yang paling banyak digunakan dan dipakai sebagai acuan tentang perkembangan kegiatan di pasar modal. Ada banyak faktor yang dapat mempengaruhi Indeks Harga Saham Gabungan (IHSG). Tujuan dari penelitian ini adalah menganalisis pengaruh variabel Nilai Tukar Mata Uang dan Tingkat Suku Bunga terhadap IHSG.

Metode analisis yang digunakan dalam penelitian ini adalah metode analisis regresi berganda dengan bantuan program SPSS (Statistic Program for Social Scienci) versi 21. Penelitian ini menggunakan data bulanan dari tahun 2009-2013 untuk tiap variabel penelitian. Hasil dari penelitian ini menunjukkan bahwa variabel Nilai Tukar Mata Uang dan Tingkat Suku Bunga berpengaruh terhadap IHSG. Selain itu diperoleh bahwa nilai adjusted $R$ square adalah $42 \%$.
\end{abstract}

\section{Keywords : Indeks Harga Saham Gabungan (IHSG), Nilai Tukar Mata Uang, Tingkat Suku Bunga}

\section{PENDAHULUAN}

Indeks Harga Saham Gabungan atau Composite Stock Price Indeks (IHSG) merupakan suatu nilai yang digunakan untuk mengukur kinerja kerja saham yang tercatat di suatu bursa efek. Menurut Sunariyah (2006:142) Indeks Harga Saham Gabungan menggambarkan suatu rangkaian informasi historis mengenai pergerakan harga saham gabungan seluruh saham, sampai pada tanggal tertentu.
IHSG dapat mencerminkan bursa efek, apakah pasar sedang dalam keadaan bullish (harga saham cenderung bergerak naik) atau dalam keadaan bearish (harga saham cenderung bergerak turun). Jika ISHG meningkat, berarti harga saham keseluruhan cenderung meningkat, demikian pula sebaliknya. Apabila IHSG menurun, harga saham keseluruhan menurun.

Bahkan saat ini Indeks Harga Saham dapat dijadikan barometer yang menunjukkan kesehatan ekonomi suatu negara dan dapat dijadikan sebagai dasar dalam menganalisis kondisi pasar (BEl,2008). Apabila terjadi peningkatan Indeks Harga Saham Gabungan maka kondisi pasar bisa dikatakan dalam kondisi baik. Contohnya jatuhnya perekonomian Amerika serikat yang ditandai dengan krisis ekonomi global pada pertengahan tahun 2008 telah meruntuhkan perekonomian di benua Eropa dan Asia, khususnya negara berkembang. Dimana Indonesia sebagai negara berkembang yang secara pelan tapi pasti terkena imbas dari krisis finansial global (Pananda Pasaribu dkk, 2009:1). 
Hal ini mengakibatkan pemerintah mengambil tindakan cepat melalui otoritas BEI dan BAPEPAM dengan melakukan penghentian perdagangan sementara dengan tujuan melindungi investor hingga pada saat kondisi normal, tetapi hal ini tidak banyak membantu karena banyaknya faktor / variabel-variabel makro seperti nilai tukar mata uang (kurs) dan tingkat suku bunga yang mempengaruhi Indeks harga Saham.

Indeks Harga Saham Gabungan kini digunakan oleh investor dalam melihat kondisi bursa yang akan digunakan untuk mengambil suatu keputusan saat melakukan transaksi saham. IHSG di BEI ini mengambil hari dasar pada tanggal 10 Agustus 1982 dan mengikutsertakan semua saham yang tercatat di BEI. Indeks ini mencakup semua saham biasa maupun saham preferen di BEI. Metode dalam penghitungan indeks harga saham gabungan yaitu dengan metode rata-rata tertimbang (Weight Average Method) (Sunariyah, 2006:144).

Krisis ekonomi yang terjadi di Indonesia pada November 2008 memaksa sektor perbankan menaikkan suku bunga ke level lebih dari 10\%. Krisis ini memicu jatuhnya Indeks Harga Saham Gabungan (IHSG) hingga melemah sebesar 30\% dalam jangka waktu yang hanya sebulan. Pada Oktober-November 2008 merupakan sinyalemen buruk bagi perekonomian Indonesia. Pelemahan IHSG terjadi seiring dengan melemahnya nilai tukar rupiah ke level lebih dari $\mathrm{Rp} 12.000$ atau mengalami pelemahan sebesar 20\% dari sebelumsebelumnya yang berada di level Rp 10.000.

Disamping itu variabel suku bunga juga ikut mempengaruhi fluktuasi harga saham dan nilai tukar. Suku bunga menjadi salah satu tolak ukur masyarakat dalam menanamkan modalnya. Pemilik modal akan mengalokasikan kekayaannya pada aset berdasarkan tingkat return dan resiko yang ada pada suatu aset. Suku bunga menjadi hal yang penting dalam pertumbuhan dan perkembangan perekonomian khususnya sektor riil serta aliran modal di suatu negara. Apabila suku bunga cenderung naik, maka pemilik modal akan mengalokasikan dananya ke dalam instrumen investasi yang lain seperti deposito (Novita dan Nachrowi, 2006).

Namun seiring dengan membaiknya perekonomian indonesia, dan juga tingkat suku bunga yang cenderung stabil di level 6,5\% dalam kurun waktu 17 bulan semenjak Agustus 2009 hingga Desember 2010. Kestabilan Nilai tukar mata uang yang dijaga oleh Bank Indonesia dan suku bunga yang cenderung stabil ikut menyumbang penguatan IHSG.

Fenomena kenaikan maupun penurunan IHSG tentunya disebabkan oleh banyak faktor atau variabel yang dapat mempengaruhi perubahan IHSG tersebut, namun di dalam tulisan ini akan berfokus kepada dua variabel independen yang lebih spesifik yaitu nilai tukar mata uang dan tingkat suku bunga.

Penelitian ini menggunakan nilai tukar mata uang (Kurs) Rupiah terhadap Dollar AS 
dengan alasan bahwa selama ini Dollar AS merupakan mata uang internasional paling stabil di dunia. Selain itu, Dollar AS merupakan mata uang internasional yang terkuat, sehingga banyak negara ataupun perusahaan yang melakukan transaksi dengan menggunakan mata uang ini (Dollar AS). Untuk tingkat suku bunga yang digunakan adalah Tingkat suku bunga SBI/BI Rate yang merupakan salah satu variabel makro ekonomi yang keberadaannya berpotensi mempengaruhi kegiatan perdagangan di lantai bursa yang tercermin dari besaran IHSG. IHSG sendiri merupakan salah satu indikator pasar modal yang sering sekali dijadikan acuan bagi pihak-pihak yang berkepentingan terhadap kegiatan di bursa efek.

Berdasarkan penelitian yang dilakukan oleh beberapa penelitian terdahulu, terdapat perbedaan hasil yang ditemukan. Penelitian yang dilakukan oleh whardane (2004) dan Rumiris L. Tobing (2009) membuktikan bahwa nilai tukar mata uang dan tingkat suku bunga tidak berpengaruh terhadap IHSG. Penelitian yang dilakukan oleh Mudji Utami (2003) dan Wiyani (2005) membuktikan bahwa Nilai tukar rupiah dan tingkat suku bunga berpengaruh signifikan terhadap harga saham. Untuk penelitian yang dilakukan oleh Nachrowi dan usman (2007) menemukan bahwa Nilai tukar Mata uang berpengaruh negatif terhadap IHSG. Kemudian penelitian yang dilakukan oleh Aditya Novianto (2008) membuktikan bahwa Kurs rupiah dan tingkat suku bunga SBI mempunyai pengaruh positif terhadap IHSG.

Berdasarkan research gap pada beberapa penelitian terdahulu, maka penulis tertarik untuk melakukan penelitian dengan cakupan masalah Indeks Harga Saham Gabungan (IHSG) sebagai variabel dependen sedangkan nilai tukar mata uang (Kurs) dalam hal ini kurs Rupiah terhadap Dollar Amerika dan tingkat suku bunga SBI sebagai variabel independen.

\section{METODE PENELITIAN}

Tempat penelitian ini dilakukan di Bursa Efek Indonesia (BEI). Data diperoleh dengan mengakses www.idx.co.id dan dari Pusat Referensi Pasar Modal (PRPM) serta menggunakan data pada Indonesian Capital Market Directory (ICMD).

Adapun variabel yang diteliti dalam penelitian ini adalah nilai tukar mata uang dan tingkat suku bunga tehadap perkembangan Indeks Harga Saham Gabungan di BEI.

Dalam penelitian ini metode yang digunakan dalam pengumpulan data adalah metode dokumentasi, yaitu dengan mencatat dan mengcopy data-data tertulis yang berhubungan dengan masalah penelitian baik dari sumber Dokumen/Buku-buku, Majalah, Internet dan lain-lain. Untuk data nilai tukar mata uang dan tingkat suku bunga diperoleh dari situs resmi Bank Indonesia dan Indeks Harga Saham Gabungan yang bersumber dari Bursa Efek Indonesia (BEI). Sedangkan metode studi pustaka dilakukan sebagai pedoman dasar dalam menggunakan literatur, 
jurnal dan sumber pustaka lainnya untuk penelitian. Jenis data yang digunakan dalam penelitian ini adalah data kuantitatif berupa data runtut waktu (time series) yaitu data yang disusun menurut waktu pada suatu variabel tertentu. Sedangakan sumber data yang digunakan yaitu data sekunder yang diperoleh dari hasil publikasi Bank Indonesia, Statistik Ekonomi dan Keuangan Indonesia (SEKI), hasil publikasi Badan Pusat Statistik (BPS) dan hasil dari Jakarta Stock Exchange (JSX) meliputi data Indeks Harga Saham Gabungan (IHSG), suku bunga sertifikat Bank Indonesia (SBI), Kurs Rupiah terhadap Dollar Amerika dengan menggunakan Kurs tengah yang dihitung atas dasar Kurs jual dan Kurs beli yang ditetapkan oleh Bank Indonesia.

Populasi dari penelitian ini adalah seluruh data Indeks Harga Saham Gabungan (IHSG), Nilai Tukar Mata Uang (Kurs) serta Tingkat Suku Bunga (SBI). Berdasarkan data yang tersedia di internet untuk semua variabel yang di gunakan dalam penelitian ini, tersedia data dari tahun 1997 sampai 2013. Sedangkan sampel penelitian ini yaitu Indeks Harga Saham Gabungan (IHSG), Nilai Tukar Mata Uang (Kurs Rupiah terhadap Dollar AS) serta Tingkat Suku Bunga (SBI)/ BI Rate yang dibatasi pada data penutupan tiap akhir bulan selama periode pengamatan antara tahun 2009-2013 sehingga didapat 60 bulan data. Alasan pemilihan data bulanan adalah untuk menghindari bias yang terjadi akibat kepanikan pasar dalam mereaksi suatu informasi, sehingga dengan penggunaan data bulanan diharapkan dapat memperoleh hasil yang lebih akurat.

\section{Metode dan Teknik Analisis Data}

Model analisis yang digunakan dalam penelitian ini adalah regresi linier berganda. Untuk ketepatan perhitungan dan mengurangi human error penelitian ini tidak melakukan perhitungan secara manual akan tetapi dengan menggunakan program komputer untuk pengolahan data statistik, yaitu dengan menggunakan program SPSS versi 21. Dengan menggunakan program SPSS disamping untuk memperoleh hasil yang akurat dan tepat, juga pengolahan data dapat dilakukan dengan cepat.

Untuk mengetahui apakah estimasi regresi yang dilakukan terbebas dari adanya gejala multikolinearitas, gejala autokorelasi, dan gejala heterokedatisitas. Untuk mengetahui ada tidaknya gejala-gejala tersebut perlu dilakukan uji terlebih dahulu dengan uji asumsi klasik.

\section{Uji Asumsi Klasik}

Uji asumsi klasik digunakan untuk mengetahui kondisi data yang digunakan dalam penelitian. Hal ini dilakukan agar diperoleh model analisis yang tepat. Uji asumsi terhadap data meliputi :

a. Uji Normalitas

Uji normalitas adalah untuk mengetahui apakah dalam model regresi, variabel terikat dan variabel bebas berdistribusi normal atau tidak normal (Imam Ghozali, 2002). Untuk mengetahui apakah berdistribusi 
normal atau tidak adalah dengan dilakukan uji Kolmogorov Smirnov, distribusi data dikatakan normal jika signifikansi > 0,05 dan dikatakan tidak normal jika signifikansi $<0,05$. Disamping menggunakan dengan uji Kolmogorov Smirnov, dapat pula dilakukan dengan menggunakan gambar histogram dan grafik normal $p$ plot yang pada prinsipnya jika data menyebar di sekitar garis diagonal dan mengikuti arah garis diagonal atau grafik histogramnya berarti menunjukkan pola berdistribusi normal, sedangkan jika data menyebar jauh dari garis diagonal dan tidak mengikuti arah garis diagonal atau grafik histogramnya berarti data tidak berdistribusi normal (Imam Ghozali, 2005).

b. Uji Multikolinearitas

Uji multikolinearitas adalah hubungan antar peubah prediktor yang signifikan dalam model regresi. Penentuan peubah prediktor yang kurang teliti atau mungkin telah diketahui hubungan tersebut tetapi peneliti mencoba memaksakan peubah tersebut tetap digunakan dalam model maka konsekuensinya setelah dilakukan uji $\mathrm{t}$ akan menghasilkan respon yang tingkat ketelitiannya rendah. Uji multikolinearitas ini bertujuan untuk menguji apakah dalam model regresi ditemukan adanya korelasi antara variabel independen.
Uji Multikolinearitas dilakukan dengan menggunakan korelasi antara variabel-variabel independen yang akan digunakan dalam persamaan regresi atau dengan menghitung nilai tolerance dan VIF (Variance Inflation Factors). Dalam model regresi yang baik seharusnya tidak terjadi korelasi di antara variabel independen. Jika variabel-variabel saling berkorelasi, maka variabel ini tidak ortogonal. Variabel ortogonal adalah variabel bebas yang nilai korelasi antar sesama variabel adalah nol (Imam Ghozali, 2002). untuk mendeteksi ada atau tidak multikolinearitas di dalam model regresi, dapat dilakukan analisis sebagai berikut :

1) Menganalisis matrik korelasi variabel-variabel bebas. Jika antar variabel bebas ada korelasi yang cukup tinggi (diatas 0,90 ) maka hal ini merupakan indikasi adanya multikolinearitas.

2) Multikolinearitas dapat juga dilihat dari nilai tolerance dan Variance Inflation Factor ( VIF ). Batas toleransi value adalah 0,10 dan VIF adalah 10. Apabila nilai tolerance value kurang dari 0,10 atau VIF lebih besar dari 10 maka terjadi multikolinearitas.

3) Nilai R2 sangat tinggi, tetapi secara individual variabel-variabel bebas banyak yang tidak signifikan mempengaruhi variabel terikat. 
c. Uji Autokorelasi

Autokorelasi adalah hubungan (korelasi) yang terjadi di antara anggota-anggota dari serangkaian pengamatan yang tersusun dalam rangkaian waktu (time series data) atau yang tersusun dalam rangkaian ruang. Uji autokorelasi bertujuan untuk menguji apakah dalam suatu model regresi linear ada korelasi antara kesalahan pengganggu pada periode $\mathrm{t}$ dengan kesalahan periode $\mathrm{t}-1$ (sebelumnya). Jika terjadi korelasi maka dinamakan ada problem autokorelasi. Model regresi yang baik adalah yang bebas autokorelasi. Untuk mendeteksi autokorelasi, dapat dilakukan uji statistik melalui uji Durbin-Watson (DW test) (Imam Ghozali, 2002). Dasar pengambilan keputusan ada tidaknya autokorelasi adalah sebagai berikut :

1. Bila nilai DW terletak diantara batas alas atau upper bound (du) dan (4-du) maka koefisien autokorelasi $=0$, berarti tidak ada autokorelasi.

2. Bila nilai DW lebih rendah dari pada batas bawah atau lower bound (dl) maka koefisien autokorelasi $>0$, berarti ada autokorelasi positif.

3. Bila nilai DW lebih besar dari (4-dl) maka koefisien autokorelasi < 0 , berarti ada autokorelasi negatif.
4. Bila nilai DW terletak diantara du dan dl atau DW terletak (4-du) dan (4-dl), maka hasilnya tidak dapat disimpulkan.

d. Uji Heteroskedastisitas

Heteroskedastisitas adalah hubungan dimana varians variabel dalam model tidak sama (Konstan). Uji heteroskedastisitas bertujuan untuk menguji apakah dalam model regresi terjadi ketidaksamaan variance dari residual satu pengamatan ke pengamatan lain. Model regresi yang baik adalah yang terjadi homokedastisitas atau tidak terjadi heteroskedastisitas. Untuk mendeteksi adanya heteroskedastisitas dilakukan dengan menggunakan uji Glejser. Dasar pengambilan keputusan uji heteroskedastisitas melalui uji Glejser dilakukan sebagai berikut :

1. Jika ada pola tertentu seperti titiktitik (point-point) yang ada membentuk suatu pola tertentu yang teratur (bergelombang, melebar kemudian menyempit), maka telah terjadi heteroskedastisitas.

2. Jika tidak ada pola yang jelas serta titik-titik menyebar di atas dan di bawah angka nol pada sumbu $Y$ maka tidak terjadi heteroskedastisitas.

Bila terjadi heteroskedastisitas akan menimbulkan varians koefisien regresi menjadi minimal 
dan confidence interval melebar, sehingga hasil uji signifikansi statistik tidak valid lagi. Salah satu cara yang digunakan untuk mendeteksi adanya heteroskedastisitas adalah dengan melihat grafik P-Plot antara nilai prediksi variabel terikat (ZPRED) dengan nilai residualnya (SRESID).

\section{Analisis Regresi Berganda}

Secara umum analisis regresi pada dasarnya adalah studi mengenai ketergantungan satu variabel terikat (Dependent) dengan satu atau lebih variabelvariabel bebas (Independent), dengan tujuan untuk mengestimasi dan memprediksi ratarata populasi atau nilai rata-rata variabel terikat (Dependent) berdasarkan nilai variabel bebas (Independent) yang diketahui. Pusat perhatian adalah pada upaya menjelaskan dan mengevaluasi hubungan antara suatu variabel dengan satu atau lebih variabel Independen. Seberapa besar variabel independen mempengaruhi variabel dependen dihitung dengan menggunakan persamaan garis regresi berganda berikut :

$$
\begin{aligned}
& \mathrm{Y}=\mathrm{a}+\mathrm{b}_{1} \mathrm{X}_{1}+\mathrm{b}_{2} \mathrm{X}_{2}+\mathrm{e} \\
& \text { Keterangan: } \\
& \text { Y } \quad=\text { IHSG (Indeks Harga Saham } \\
& \text { Gabungan) } \\
& \text { a }=\text { Konstanta } \\
& \mathrm{b}_{1}-\mathrm{b}_{2}=\text { Koefisien Garis Regresi } \\
& \mathrm{X}_{1}=\text { Nilai Tukar Mata Uang } \\
& \mathrm{X}_{2}=\text { Tingkat Suku Bunga }
\end{aligned}
$$

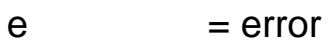

Ketepatan fungsi regresi sampel dalam menaksir nilai aktual dapat diukur dari Goodness of Fit-nya. Secara statistik, setidaknya ini dapat diukur dengan metode berikut :

a. Koefisien Determinasi $\left(R^{2}\right)$

$$
\mathrm{Kd}\left(\mathrm{R}^{2}\right) \text { digunakan untuk mengukur }
$$
seberapa jauh kemampuan model dalam menerangkan variabel dependen. Nilai Kd adalah antara 0 dan 1 . Nilai $R$ yang kecil berarti kemampuan variabel-variabel independen dalam menerangkan variabel dependen sangat terbatas. Nilai yang mendekati 1 berarti variabel independen memberikan hampir semua informasi yang dibutuhkan untuk memprediksi variasi variabel independen.

b. Uji t (pengujian secara parsial)

Uji statistik $t$ pada dasarnya menunjukkan seberapa jauh pengaruh satu variabel penjelas/independen secara individual dalam menerangkan variasi variabel dependen.

c. Uji F (pengujian secara simultan)

Uji $F$ dilakukan untuk melihat apakah semua variabel-variabel independent yang dimasukkan dalam model mempunyai pengaruh secara simultan terhadap variabel dependen.

\section{HASIL PENELITIAN DAN PEMBAHASAN}

\section{Statistik Deskriftif}

Statistik Deskriftif dalam penelitian ini bertujuan untuk memberikan gambaran umum 
tentang data yang telah di olah yang terdiri dari frekuensi, mean dan standar deviasi.

Berikut ini tabel data deskriftif :

Tabel 1

Statistika Deskriptif IHSG

Residuals Statistics ${ }^{a}$

\begin{tabular}{|l|r|r|r|r|r|}
\hline \multicolumn{1}{|c|}{ Model } & Minimum & Maximum & Mean & Std. Deviation & N \\
& & & & & \\
\hline Predicted Value & 1285,4757 & $5.068,6280$ & 3516,0688 & 637,32080 & 60 \\
Residual & $-1470,04858$ & 1700,64661 &, 00000 & 719,17480 & 60 \\
Std. Predicted Value & $-3,219$ & 1,305 &, 000 & 1,000 & 60 \\
Std. Residual & $-2,009$ & 2,324 &, 000 &, 983 & 60 \\
\hline
\end{tabular}

a. Dependent Variable: IHSG

Dari hasil perhitungan di atas dengan jumlah pengamatan selama 60 bulan dimulai dari bulan Januari tahun 2009 hingga bulan Desember tahun 2013, dapat dilihat bahwa nilai terendah IHSG adalah 1285,4757 yang terjadi pada bulan Februari tahun 2009, sementara nilai tertinggi IHSG adalah 5068,6280 yang terjadi pada bulan Mei tahun 2013. Nilai rata-rata IHSG adalah sebesar 3516,0688 dengan standar deviasi sebesar 637,32080 . Dengan nilai standar deviasi yang sangat besar ini menandakan bahwa nilai IHSG berfluktuasi tajam. Hal ini dapat dilihat pada grafik berikut ini :

\section{Gambar 1 \\ Hasil Uji Normalitas dengan Histogram Grafik Normal}

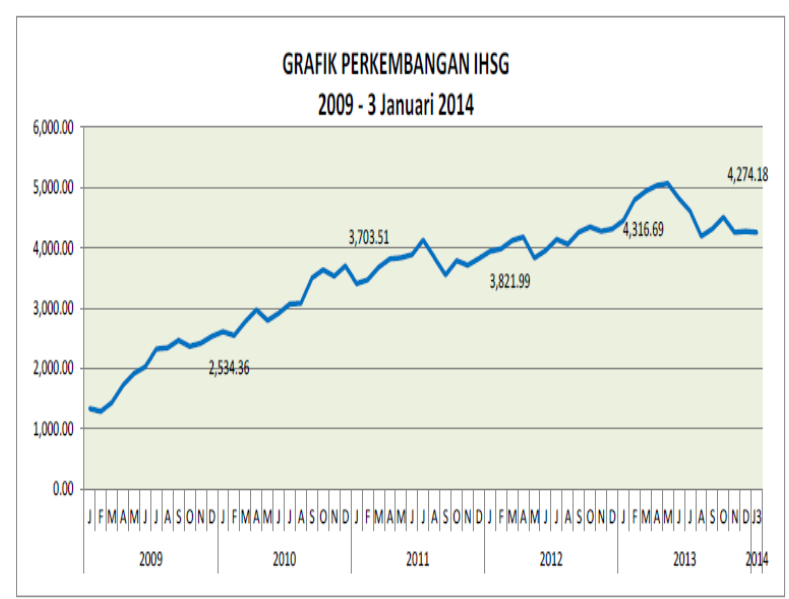

\section{Pengujian Asumsi Klasik}

Model yang digunakan untuk menganalis data dalam penelitian ini adalah menggunakan regresi linier berganda dan uji hipotesis dengan menggunakan uji t dan uji $F$. Sebelum membahas tentang analisis data, 
terlebih dahulu dilakukan uji asumsi klasik yang digunakan untuk mengetahui gangguangangguan atau persoalan-persoalan pada regresi linier berganda.

a. Uji Normalitas Data

Pengujian distribusi data bertujuan untuk menguji suatu data penelitian apakah dalam model statistik, variabel terikat dan variabel bebas berdistribusi normal atau berdistribusi tidak normal. Untuk mengetahui distribusi data suatu penelitian, salah satu alat yang digunakan adalah menggunakan uji Kolmogorov Smirnov. Menurut Imam Ghozali (2005), bahwa distribusi data dapat dilihat dengan membandingkan $Z$ hitung dengan $Z$ tabel dengan kriteria sebagai berikut :

- Jika Z hitung (Kolmogorov Smirnov) $<Z$ tabel $(1,96)$, maka distribusi data dikatakan normal.

- Jika Z hitung (Kolmogorov Smirnov) $>Z$ tabel $(1,96)$, maka distribusi data dikatakan tidak normal.

Berdasarkan hasil data penelitian pada nilai residual memiliki angka $Z$ hitung (Kolmogorov Smirnov) sebesar 1, $305<$ 1,96 sehingga termasuk distribusi data yang normal. Selain dengan menggunakan angka statistik dengan uji Kolmogorov Smirnov, dapat pula dilihat dengan grafik normal $p$-plot dan histogram sebagai berikut :

\section{Gambar 2 dan 3 \\ Hasil Uji Normalitas dengan Histogram Grafik Normal P-Plot}

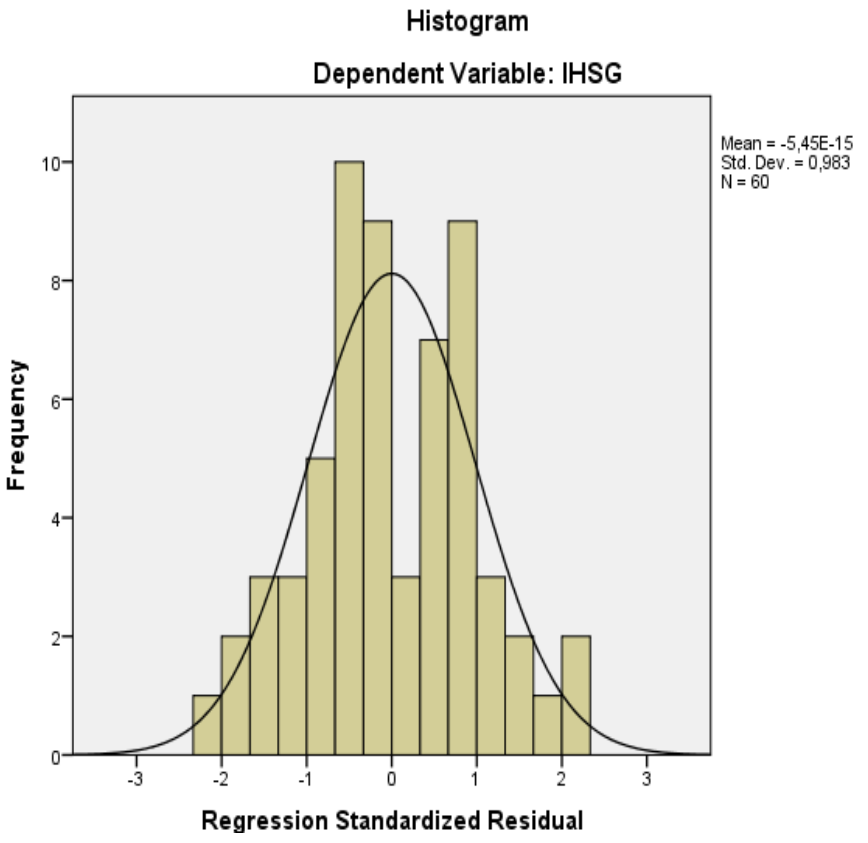

Normal P-P Plot of Regression Standardized Residual

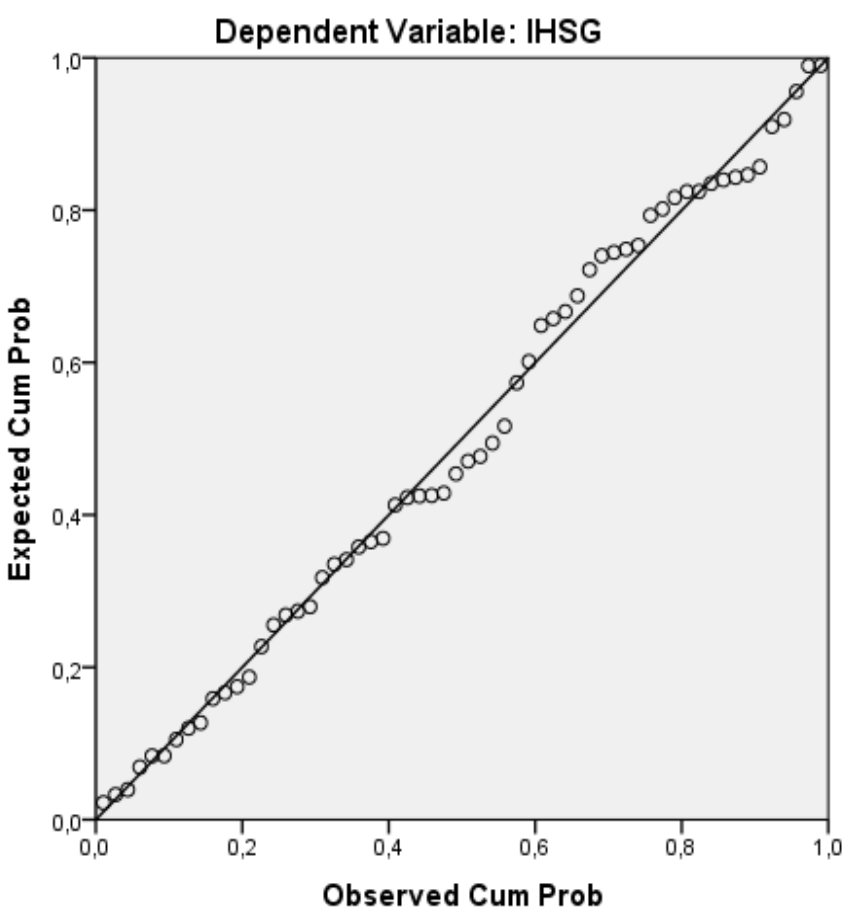


a. Uji Multikolinearitas

Uji multikolinearitas bertujuan untuk menguji apakah dalam model regresi ditemukan adanya korelasi antar variabel bebas. Model regresi yang baik seharusnya tidak terjadi korelasi diantara variabel bebas. Jika variabel bebas saling berkorelasi, maka variabel-variabel ini tidak orthogonal. Variabel orthogonal adalah variabel bebas yang nilai korelasi antar sesama variabel bebas sama dengan nol. Multikolinearitas dapat dilihat dari nilai tolerance dan Variance Inflation Factor (VIF). Regresi bebas dari gangguan multikolinearitas apabila nilai VIF kurang dari 10 (Ghozali, 2005). Hasil uji multikolinearitas dapat dilihat pada tabel berikut ini :

Tabel 2

Hasil Uji Multikolinearitas Coefficients $^{a}$

\begin{tabular}{|rl|r|r|}
\hline \multicolumn{2}{|l|}{ Model } & \multicolumn{2}{|c|}{ Collinearity Statistics } \\
\cline { 3 - 4 } & (Constant) & Tolerance & \multicolumn{1}{c|}{ VIF } \\
\hline \multirow{2}{*}{1} & KURS &, 775 & 1,290 \\
& SBI &, 775 & 1,290 \\
\hline
\end{tabular}

Hasil yang diperoleh dalam angka VIF ini nilainya $<10$ yaitu VIF untuk variabel nilai tukar mata uang $\left(X_{1}\right)$ sebesar 1,290. VIF variabel suku bunga $\mathrm{SBI}\left(\mathrm{X}_{2}\right)$ sebesar 1.290. Melihat hasil VIF pada semua variabel penelitian yaitu $<10$, maka data-data penelitian digolongkan tidak terdapat gangguan multikolinearitas dalam model regresi.
Uji autokorelasi bertujuan untuk menguji apakah dalam suatu model regresi linier ada korelasi antar anggota sampel yang diurutkan berdasarkan waktu. Penyimpangan asumsi ini biasanya muncul pada observasi yang menggunakan data time series.

Gejala autokorelasi dideteksi dengan menggunakan Uji Durbin-Watson (DW). Untuk mendeteksi ada tidaknya autokorelasi harus dilakukan pengujian Durbin-Watson (DW) dengan nilai d hasil penelitian dibandingkan dengan nilai $d_{\text {tabel }}$ dengan tingkat signifikasi $5 \%$ dengan $d f=$ $\mathrm{n}-\mathrm{k}-1$. Dari hasil pengujian terlihat bahwa nilai DW sebesar 0,214. Hal ini berarti data tidak terkena autokorelasi, oleh karena itu model regresi ini dinyatakan layak untuk dipakai.

b. Uji Autokorelasi 
Tabel 3

Hasil Uii Autokorelasi (Nilai Durbin-Watson)

Model Summary ${ }^{b}$

\begin{tabular}{|l|r|r|r|r|c|}
\hline Model & $\mathrm{R}$ & R Square & \multicolumn{1}{|c|}{$\begin{array}{c}\text { Adjusted R } \\
\text { Square }\end{array}$} & $\begin{array}{c}\text { Std. Error of the } \\
\text { Estimate }\end{array}$ & Durbin-Watson \\
\hline 1 &, $663^{\mathrm{a}}$ &, 440 &, 420 & 731,68313 &, 214 \\
\hline
\end{tabular}

a. Predictors: (Constant), SBI, KURS

b. Dependent Variable: IHSG

a. Uji Heteroskedastisitas

Uji Heteroskedastisitas bertujuan untuk menguji apakah dari model regresi terjadi ketidaksamaan varians dari residual satu pengamatan ke pengamatan yang lain. Model regresi yang baik adalah yang homoskedastisitas atau tidak terjadinya heteroskedastisitas.
Salah satu cara untuk mendeteksi ada atau tidaknya heteroskedastisitas adalah dengan melihat grafik plot antara nilai prediksi variabel terikat dengan residualnya. Jika ada pola tertentu, seperti titik-titik menyebar di atas dan di bawah angka 0 pada sumbu $Y$, maka tidak terjadi heteroskedastisitas.

\section{Gambar 4}

\section{Hasil Uii Heteroskedastisitas}

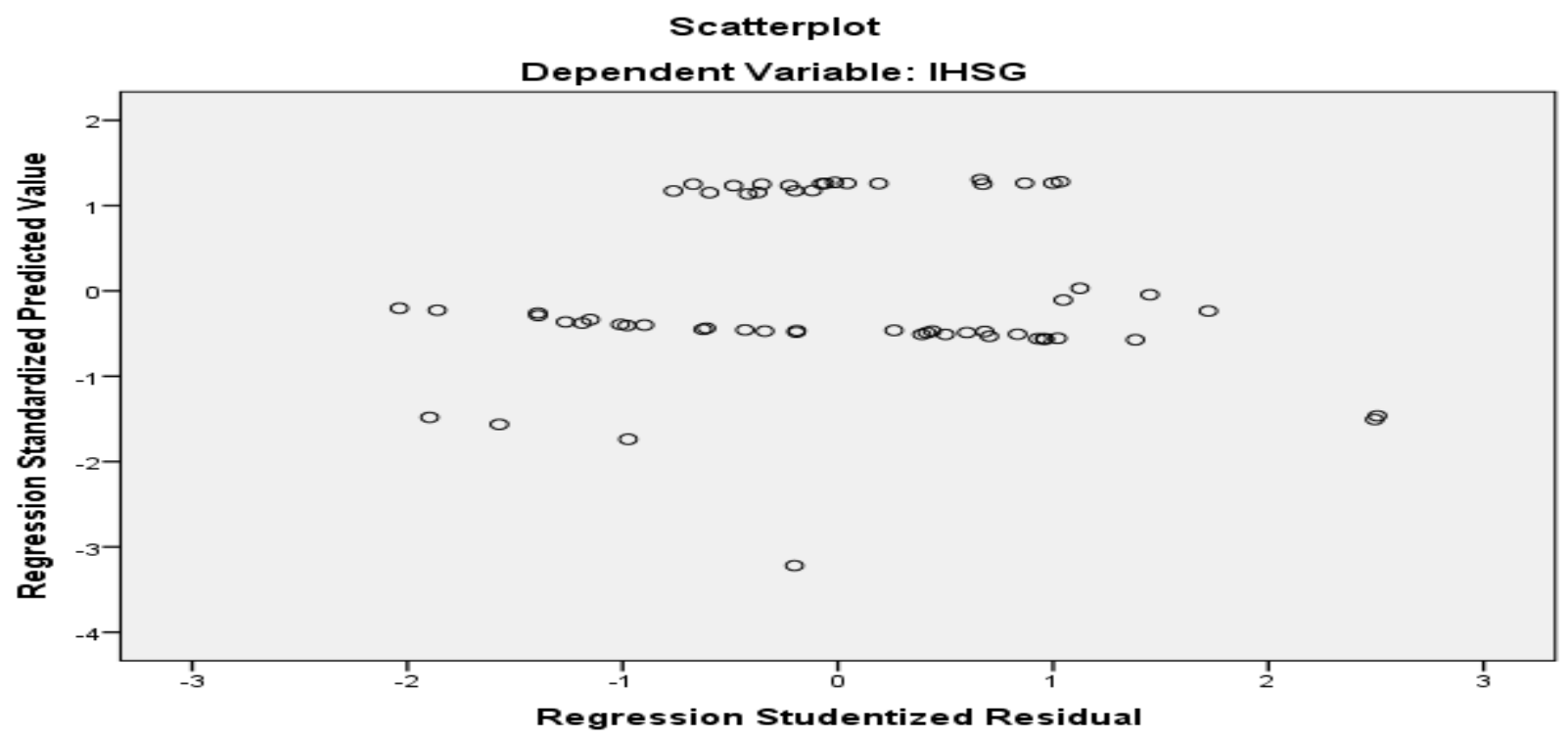


terlihat ada pola tertentu, serta titik-titik menyebar di atas dan di bawah angka 0 pada sumbu $\mathrm{Y}$, maka tidak terjadi heteroskedastisitas.
Selain itu untuk melihat apakah dari model regresi terjadi ketidaksamaan varians dari residual satu pengamatan ke pengamatan yang lain dapat dilihat pada tabel berikut :

Tabel 4

\section{Uii Koefisien Spearrman's rho Correlations}

\section{Correlations}

\begin{tabular}{|l|l|r|}
\hline & & Unstandardized Residual \\
\hline \multirow{4}{*}{ KURS } & Correlation Coefficient &,- 157 \\
& Sig. (2-tailed) &, 230 \\
& $N$ & 60 \\
& Correlation Coefficient & \\
& Sig. (2-tailed) &,- 027 \\
& $N$ &, 840 \\
& & 60 \\
Unstandardized & Correlation Coefficient & \\
Residual & Sig. (2-tailed) & 1,000 \\
& $N$ & 60 \\
\hline
\end{tabular}

\section{Berdasarkan hasil pengujian} heteroskedastisitas di atas terlihat bahwa semua variabel bebas tidak signifikan terhadap nilai absolut residual regresi yang terbentuk bebas dari gejala heteroskedastisitas.

\section{Analisis Regresi dan Uji Hipotesis}

a. Analisis Regresi

Hasil pengujian asumsi klasik yang telah dilakukan, dapat disimpulkan bahwa model regresi dalam penelitian ini layak digunakan karena model regresi telah terbebas dari masalah normalitas data, tidak terjadi multikolinearitas, tidak terjadi autokorelasi, dan tidak terjadi heterokedastisitas. Selanjutnya analisis regresi dilakukan untuk mengetahui pengaruh antar variabel independen dan variabel dependen. Dalam penelitian ini analisis yang digunakan adalah regresi berganda dengan cara memasukkan seluruh variabel sehingga dapat diketahui seberapa besar pengaruh variabel independen terhadap variabel dependen. Adapun hasil analisis persamaan regresi dapat dilihat pada tabel berikut : 
Tabel 5

Hasil Analisis Rearesi

\begin{tabular}{|l|r|r|r|r|r|}
\hline Model & \multicolumn{2}{|c|}{ Unstandardized Coefficients } & \multicolumn{1}{c|}{$\begin{array}{c}\text { Standardized } \\
\text { Coefficients }\end{array}$} & \multicolumn{1}{c|}{ Sig. } \\
\cline { 2 - 4 } & \multicolumn{1}{|c|}{$\mathrm{B}$} & Std. Error & \multicolumn{1}{c|}{ Beta } & & \\
\hline (Constant) & 9240,770 & 1164,776 & & 7,934 &, 000 \\
1 KURS &, 128 &, 120 &, 120 & 1,068 &, 029 \\
SBI & $-102666,400$ & 16239,794 &,- 712 & $-6,322$ &, 000 \\
\hline
\end{tabular}

Berdasarkan hasil regresi linear di atas, model analisis regresi berganda yang digunakan dalam penelitian ini dapat dirumuskan sebagai berikut :

$Y=9240,770+0,128+(-102666,4)+e$

Dari persamaan regresi tersebut dapat diungkapkan :

1. Konstanta menunjukkan angka sebesar 9240,770 yang berarti tanpa variabel independen Indeks Harga Saham Gabungan (IHSG) sudah mencapai 9240,770. Hal ini menandakan adanya pengaruh variabel lain selain Nilai tukar mata uang dan Tingkat suku bunga SBI.

2. Nilai tukar mata uang (Kurs) menunjukkan angka 0,128 mempunyai arti bahwa jika Tingkat suku bunga SBI dalam keadaan konstan maka setiap peningkatan Nilai tukar mata uang sebesar 1 poin akan meningkatkan nilai Indeks Harga Saham Gabungan (IHSG) sebesar 0,128 .
3. Tingkat suku bunga

(SBI) menunjukkan angka -102666,4 mempunyai arti bahwa jika Nilai tukar mata uang dalam keadaan konstan maka setiap peningkatan Tingkat suku bunga SBI sebesar $1 \%$ akan menurunkan nilai Indeks Harga Saham gabungan (IHSG) sebesar 102666,4.

b. Uji Koefisien Determinasi $\left(\mathrm{R}^{2}\right)$

Pada penelitian ini, analisis koefisien determinasi dimaksudkan untuk mengetahui seberapa besar keterkaitan antara variabel bebas yaitu nilai tukar mata uang dan tingkat suku bunga dengan hasil uji sebagai berikut : 
Tabel 6

Koefisien Determinasi $\left(\mathbf{R}^{2}\right)$

Model Summary ${ }^{b}$

\begin{tabular}{|l|r|r|r|r|}
\hline Model & $\mathrm{R}$ & \multicolumn{1}{|c|}{ R Square } & Adjusted R Square & Std. Error of the Estimate \\
& & & & \\
\hline 1 &, $663^{\mathrm{a}}$ &, 440 &, 420 & 731,68313 \\
\hline
\end{tabular}

a. Predictors: (Constant), SBI, KURS

b. Dependent Variable: IHSG

Pada penelitian ini nilai koefisien determinasi (Adjusted $\mathrm{R}^{2}$ ) adalah sebesar 0,420 . Hal ini berarti bahwa variabel nilai tukar mata uang (Kurs) dan tingkat suku bunga (SBI) sebesar 42\%. Sedangkan sisanya yaitu sebesar $100 \%-42 \%=58 \%$ dijelaskan oleh faktor-faktor lain selain variabel yang diteliti di atas.

c. Uji t (Pengujian secara parsial)

Uji t digunakan untuk mengetahui apakah variabel-variabel independen
Secara parsial berpengaruh nyata atau tidak terhadap variabel dependen. Derajat signifikansi yang digunakan adalah 0,05. Apabila nilai signifikan lebih kecil dari derajat kepercayaan maka kita menerima hipotesis alternatif, yang menyatakan bahwa suatu variabel independen secara parsial mempengaruhi variabel dependen. Berikut ini adalah tabel dari hasil pengujian :

Tabel 7

Hasil Analisis Uji t

Coefficients $^{\mathrm{a}}$

\begin{tabular}{|l|r|r|r|r|r|}
\hline Model 1 & \multicolumn{2}{|c|}{ Unstandardized Coefficients } & \multicolumn{1}{|c|}{$\begin{array}{c}\text { Standardized } \\
\text { Coefficients }\end{array}$} & \multicolumn{1}{|c|}{ Sig. } \\
\cline { 2 - 4 } & \multicolumn{1}{|c|}{$\mathrm{B}$} & \multicolumn{1}{|c|}{ Std. Error } & Beta & & \\
\hline (Constant) & 9240,770 & 1164,776 & & 7,934 &, 000 \\
KURS &, 128 &, 120 &, 120 & 1,068 &, 029 \\
SBI & $-102666,400$ & 16239,794 &,- 712 & $-6,322$ &, 000 \\
\hline
\end{tabular}

a. Dependent Variable: IHSG 
Hasil uji statistik tersebut menunjukkan bahwa :

1. Nilai Tukar Mata Uang (Kurs) Terhadap Indeks Harga Saham Gabungan (IHSG)

Berdasarkan tabel di atas, dapat diketahui bahwa nilai tukar mata uang (kurs) menghasilkan nilai t hitung sebesar 1,068. Variabel ini mempunyai tingkat signifikansi sebesar 0,029 yang apabila dibandingkan dengan derajat kesalahan yang telah ditentukan yaitu sebesar $5 \%$ atau 0,05 , variabel ini termasuk signifikan. Nilai signifikansi variabel nilai tukar mata uang lebih kecil dari derajat kesalahan yang artinya bahwa $\mathrm{H}_{0}$ ditolak dan $\mathrm{H}_{1}$ dapat diterima. Dari hasil uji t disimpulkan bahwa nilai tukar mata uang (Kurs) berpengaruh signifikan terhadap perkembangan Indeks Harga Saham Gabungan (IHSG). Jadi secara parsial variabel nilai tukar mata uang (Kurs) memberikan pengaruh secara signifikan terhadap Indeks Harga Saham Gabungan (IHSG). Koefisien regresi variabel Kurs sebesar 0,128 bermakna jika variabel kurs meningkat 1 poin, maka akan berpengaruh terhadap satu satuan IHSG sebesar 0,128 poin.

Dengan kata lain bila ada penguatan nilai tukar rupiah sebesar 1 (ditandai dengan mengecilnya nominal angka) maka berpengaruh secara langsung terhadap IHSG meningkat 0,128 . Misalkan perusahaan yang berorientasi impor, depresiasi kurs rupiah terhadap dollar Amerika yang tajam akan berdampak negatif terhadap harga saham perusahaan. Sementara itu, perusahaan yang berorientasi ekspor akan menerima dampak positif dari depresiasi kurs rupiah terhadap dollar Amerika. Ini berarti harga saham yang terkena dampak negatif akan mengalami penurunan di Bursa Efek Indonesia (BEI), sementara perusahaan yang terkena dampak positif akan mengalami kenaikan harga sahamnya. Selanjutnya, Indeks Harga Saham Gabungan (IHSG) juga akan terkena dampak negatif atau positif tergantung pada kelompok yang dominan dampaknya. Keadaan ini memudahkan investor menggunakan informasi nilai tukar mata uang dalam membuat keputusan investasi karena adanya pola yang kuat antara kedua variabel tersebut saling mempengaruhi yang juga sejalan dengan literatur yang dikembangkan oleh Flood \& Garber (1984).

2. Tingkat Suku Bunga (SBI) Terhadap Indeks Harga Saham Gabungan (IHSG)

Dari hasil regresi diketahui bahwa tingkat suku bunga (SBI) menghasilkan nilai t hitung sebesar 6,322 . Variabel ini mempunyai tingkat 
signifikansi sebesar 0,000 yang apabila dibandingkan dengan derajat kesalahan yang telah ditentukan yaitu sebesar $5 \%$ atau 0,05 , dimana Nilai signifikansi variabel tingkat suku bunga SBI lebih kecil dari derajat kesalahan yang artinya bahwa $\mathrm{H}_{0}$ ditolak dan $\mathrm{H}_{1}$ dapat diterima. Dari hasil uji t disimpulkan bahwa tingkat suku bunga (SBI) berpengaruh negatif dan signifikan terhadap perkembangan Indeks Harga Saham Gabungan (IHSG) secara parsial. Kenaikan tingkat suku bunga (SBI) $1 \%$ akan menyebabkan penurunan Indeks Harga Saham Gabungan (IHSG) sebesar -102666,400. Hal ini dikarenakan, kenaikan tingkat suku bunga (SBI) mendorong investor mengalihkan dananya dari pasar modal ke pasar uang sehingga mengakibatkan Indeks Harga Saham Gabungan (IHSG) mengalami penurunan.
Hasil penelitian ini sesuai dengan penelitian yang dilakukan oleh Wahyu Wiyani (2005), Mudji Utami dan Mudjilah Rahayu (2003) dimana hasil penelitiannya diperoleh bahwa ada pengaruh yang signifikan antara nilai tukar mata uang dan tingkat suku bunga SBI terhadap perkembangan Indeks Harga Saham Gabungan (IHSG) secara parsial.

d. Uji f (Pengujian Secara Simultan)

Uji $F$ dilakukan untuk menunjukkan apakah secara simultan semua variabel independen yang dimasukkan dalam model regresi berpengaruh terhadap variabel dependen. Secara simultan signifikansi model regresi diuji dengan melihat perbandingan antara F-tabel dan Fhitung. Selain itu akan dilihat nilai signifikansi, dimana jika nilai sig $<0,05$ maka variabel independen dinyatakan berpengaruh terhadap variabel dependen. Adapun hasil pengujiannya dapat dilihat pada tabel di bawah ini :

Tabel 8

Hasil Analisis Uii f

ANOVA $^{a}$

\begin{tabular}{|l|r|r|r|r|r|}
\hline Model & \multicolumn{1}{|c|}{ Sum of Squares } & \multicolumn{1}{c|}{ df } & Mean Square & F & Sig. \\
\hline Regression & 23964490,662 & 2 & 11982245,331 & 22,382 &, $000^{b}$ \\
Residual & 30515531,586 & 57 & 535360,203 & & \\
Total & 54480022,249 & 59 & & & \\
\hline
\end{tabular}

a. Dependent Variable: IHSG 
Tabel 8 menunjukkan bahwa nilai $F_{\text {hitung adalah 22,382 dengan tingkat }}$ signifikansi 0,000 . sedangkan nilai $F_{\text {tabel }}$ terlebih dahulu dilakukan dengan beberapa tahapan yaitu mencari nilai df1 dan df2. Dengan jumlah sampel $(n)=60$ dan jumlah variabel $(k)=2$ serta $\alpha=0,05$ diperoleh df1 $(\mathrm{k}-1=2-1)=1$ dan df2 $(\mathrm{n}-\mathrm{k}-1=60-2-1)=57$. Berdasarkan hasil dari df1 dan df2 maka diperoleh nilai $F_{\text {tabel }}$ sebesar 5,35 (dibulatkan). Uji $F$ dilakukan dengan membandingkan antara $F_{\text {hitung }}$ dengan $F_{\text {tabel. }}$ Jika $F_{\text {hitung }}<F_{\text {tabel }}$ pada taraf signifikansi ( $\alpha$ 0,05), maka $H_{1}$ ditolak dan sebaliknya bila $F_{\text {hitung }}>F_{\text {tabel }}$ pada taraf signifikansi $(\alpha 0,05)$, maka $\mathrm{H}_{1}$ diterima. Oleh karena $F_{\text {tabel }}$ pada tingkat kepercayaan 95\% (a 0,05) adalah 5,35 maka dilakukan perbandingkan antara $F_{\text {hitung }}$ dengan $F_{\text {tabel }}$ dimana nilai $F_{\text {hitung }}>F_{\text {tabel }}(22,382>5,35)$ dan signifikansi lebih kecil dari 0,05 (0,000< 0,05). Hal ini menunjukkan bahwa secara simultan variabel independen nilai tukar mata uang (Kurs) dan tingkat suku bunga (SBI) berpengaruh secara signifikan terhadap perkembangan Indeks Harga Saham Gabungan (IHSG).

Berdasarkan hasil analisis data di atas dapat ditarik kesimpulan bahwa diketahui nilai tukar mata uang dan tingkat suku bunga secara Simultan (bersama-sama) dapat mempengaruhi perkembangan Indeks Harga Saham Gabungan. Jika dihitung secara parsial (individu) variabel Nilai Tukar Mata Uang berpengaruh signifikan dan Tingkat Suku Bunga berpengaruh negatif signifikan terhadap Indeks Harga Saham Gabungan.

\section{SIMPULAN}

Berdasarkan hasil penelitian dan pembahasan maka diperoleh kesimpulan sebagai berikut :

1. Nilai Tukar Mata Uang berpengaruh signifikan terhadap perkembangan Indeks Harga Saham Gabungan, Keadaan ini memudahkan investor menggunakan informasi nilai tukar mata uang dalam membuat keputusan investasi karena adanya pola yang kuat antara kedua variabel tersebut saling mempengaruhi.

2. Tingkat Suku Bunga berpengaruh negatif dan signifikan terhadap perkembangan Indeks Harga Saham Gabungan, Hal ini dikarenakan kenaikan tingkat suku bunga mendorong investor mengalihkan dananya dari pasar modal ke pasar uang sehingga mengakibatkan Indeks Harga Saham Gabungan mengalami penurunan.

3. Pada penelitian ini nilai koefisien determinasi (Adjusted $\mathrm{R}^{2}$ ) adalah sebesar 0,420 . Hal ini berarti bahwa variabel nilai tukar mata uang (Kurs) dan tingkat suku bunga (SBI) sebesar 42\%. Sedangkan sisanya yaitu sebesar $100 \%-42 \%=58 \%$ dijelaskan oleh faktor-faktor lain selain variabel yang diteliti.

\section{KETERBATASAN PENELITIAN}

Penelitian ini memiliki banyak keterbatasan sehingga membutuhkan perbaikan untuk peneliti selanjutnya. Adapun keterbatasan yang dialami dalam penelitian ini yaitu : 
1. Penentuan sampel yang hanya pada periode 2009-2013 yang sebagian besar rentang data berada pada kondisi nilai tukar mata uang dan tingkat suku bunga yang normal dan stabil.

2. Penelitian hanya memiliki Indeks Harga Saham Gabungan padahal perlu juga dikaji indeks saham sektor lain.

3. Penelitian ini hanya menggunakan variabel nilai tukar mata uang dan tingkat suku bunga saja sebagai indikator indeks harga saham gabungan, padahal masih banyak lagi faktor-faktor lain yang bisa mempengaruhi penelitian.

4. Penelitian ini hanya menggunakan dua variabel makro ekonomi dan tidak memperhatikan faktor kondisi sosial politik dan keamanan yang terjadi di Indonesia yang juga mempengaruhi kinerja pasar saham.

5. Penelitian ini hanya menggunakan satu metode sehingga diperlukan studi lanjutan yang lebih mendalam dengan data dan metode yang lebih lengkap sehingga dapat melengkapi hasil penelitian yang telah ada.

\section{SARAN}

Berdasarkan kesimpulan penelitian ini, penulis memberikan beberapa saran sebagai berikut :

1. Bagi peneliti selanjutnya perlu menambahkan jumlah tahun sampel mulai tahun 1997 awal mula krisis ekonomi di Indonesia sehingga akan lebih jelas pola hubungan antara setiap variabel terutama variabel nilai tukar mata uang.

2. Untuk penelitian selanjutnya dapat dilakukan dengan menambahkan faktor makro ekonomi baik dari dalam maupun luar negeri.

3. Penelitian lebih lanjut dapat membandingkan periode penelitian yaitu antara periode sebelum krisis ekonomi, setelah krisis ekonomi dan pada saat krisis finansial global sehingga akan diketahui konsistensi variabel tersebut dalam melihat pengaruh faktor-faktor yang mempengaruhi Indeks Harga Saham Gabungan (IHSG).

\section{DAFTAR PUSTAKA}

Ang, Robbert.1997, " Pasar Modal Indonesia”. Mediasoft Jakarta.

Bank Indonesia. Statistik Ekonomi dan Keuangan Indonesia.

Bursa Efek Indonesia., 2014, Buku Panduan Indeks Harga Saham Bursa efek Indonesia.

Ghozali, Imam. 2002. Aplikasi Analisis Multivariate Dengan Program SPSS. Semarang : Badan Penerbit Undip.

Ghozali, Imam. 2005. Aplikasi Analisis Multivariate Dengan Program SPSS. Semarang : Badan Penerbit Undip.

Maryanti, Sri. 2009. "Analisis Pengaruh Tingkat Bunga SBI dan Nilai Kurs Dolar AS Terhadap Indeks Harga Saham Gabungan (IHSG) (Studi Pada Bursa Efek Jakarta)." Pekbis Jurnal, Vol. 1 Fakultas Ekonomi, Universitas Lancang Kuning. Pekanbaru. 
Mankiw, N. Gregory. 2003. Teori Makro Ekonomi. Edisi 5. Jakarta: Erlangga.

Mauliano, Deddy Azhar. 2009. Analisis Faktor-Faktor Yang Mempengaruhi Pergerakan Indeks Harga Saham Gabungan (IHSG) di Bursa Efek Indonesia. Universitas Gunadarma, Depok.

Mudji Utami dan Mudjilah Rahayu, 2003, Peranan Profitabiliatas, Suku Bunga, Inflasi Dan Nilai Tukar Dalam Mempengaruhi Pasar Modal Indonesia Selama Krisis Ekonomi. Jurnal Manajemen \& Kewirausahaan Vol.5 no.2 September 2003 : 123 -131.

Mulyono, Sugeng, 2000. Pengaruh Earning Per Share (EPS) dan Tingkat Bunga Terhadap Harga Saham. Jurnal Ekonomi dan Manajemen Vol. 1 No. 2 Desember.

Oktavilia, Shanty. 2003. Analisis Pengaruh Variabel Ekonomi Makro Terhadap Perkembangan Harga Saham di BEJ Periode 1990-2000. Skripsi Tidak Dipublikasikan. Universitas

Diponegoro, Semarang.

Pratikno, Dedy. 2006. Analisis Pengaruh Nilai Tukar Rupiah, Inflasi, SBI, dan Indeks Dow Jones Terhadap Pergerakan Indeks Harga Saham Gabungan (IHSG) di Bursa Efek Indonesia (BEI). Jurnal Riset Ekonomi dan Manajemen.

Rahayu, Puji Theresia. 2002. Analisis Pengaruh Nilai Tukar dan Suku Bunga Terhadap IHSG di BEJ. Skripsi Tidak Dipublikasikan. Universitas Diponegoro, Semarang.

Sunariyah, 2006, Pengantar Pengetahuan Pasar Modal, Edisi Kelima, UPP STIM YKPN, Yogyakarta.

Tandelin, Eduardus, 2000, "Pasar modal Indonesia: Problem dan Prospek". Wahana, volume 3, No.2.
Tobing dan Manurung, 2008, "Pengaruh Variabel Makroekonomi terhadap IHSG".

Utami. M.dan Rahayu, M., 2003, "Peranan Profitabilitas, Suku Bunga, Inflasi dan Nilai Tukar Dalam Mempengaruhi Pasar Modal Indonesia Selama Krisis Ekonomi”, Jurnal Ekonomi Manajemen, Vol.5, No.2.

Wiyani, Wahyu dan Wijayanto, Andi, 2005. Pengaruh Nilai Tukar Rupiah, Tingkat Suku Bunga Deposito dan Volume Perdagangan Saham terhadap Harga Saham, Jurnal Keuangan dan Perbankan, Tahun IX, No. 3 September.

Situs Website Resmi Bank Indonesia :

http://www.bi.go.id

Situs Website Resmi BEl : http://www.idx.co.id

Situs Website Resmi Bapepem : http://www.bapepam.go.id

Situs Website www.yahoo.finance.com

Situs Website www.jsx.co.id

Situs Website www.id.wikipedia.org 